\title{
THE EFFECTS OF NATURAL PAINT ON THE MOISTURE BUFFERING ABILITY OF PAPER PLASTER
}

\author{
N. Nutt", A. Kubjas, L. Nei, A. Ruus \\ Tartu College, School of Engineering, Tallinn University of Technology \\ Puiestee 78, 51008 Tartu, ESTONIA \\ *e-mail: nele.nutt@taltech.ee
}

The scope of the Nordtest method is to evaluate the moisture buffer value (MBV) of materials exposed to indoor air. The test is intended to simulate daily variations with relative humidity (RH) between $75 \%$ during 8 hours and $33 \%$ during 16 hours.

The specimens follow a recipe that consists of waste paper, glue and water. Specimens made of paper plaster were covered with different colours.

The results of the experiment showed that the type of paint used and the number of layers applied affected the MBV. Natural colours have a better moisture permeability than chemical paints, but the number of natural colour layers affects the MBV. The higher the number of layers, the lower the MBV.

Keywords: Buffer effect, building materials, humidity, indoor climate, moisture buffer value, material properties, moisture transport, Nordtest, natural paint, paper plaster, recycle, wastepaper.

\section{INTRODUCTION}

In moderate to cold climates, people usually spend about $90 \%$ of their time in enclosed spaces, so the indoor climate is a crucial factor of well-being [1]. The moisture buffering value (MBV) has been studied by several authors [2], [3], [4], [5]. The results of earlier laboratory studies about the interior plaster made of waste paper have shown that the MBV of paper plaster is excellent $(\mathrm{MBV}>2.0=$ "excellent") regardless of the type of paper [6], paper with clay [7], [8] or of the technology used to shred the paper [9].

The MBVs of waste paper of reusable materials [6] and MBVs of different clay plasters [10] have been studied. The effects 
of coating on the clay plaster hygroscopicity and water vapour permeability have also been researched [11]. However, the effects of coating on the hygroscopic abilities of paper plaster have not been studied.

Thickness of layer and water vapour transmission properties could be very differ- ent [12]. Water vapour transmission rate of casein paint and egg tempera (1-layer paint) were recorded as paints with "high" water vapour transmission rate $\left(>150 \mathrm{~g} /\left(\mathrm{m}^{2} \mathrm{~d}\right)\right.$, while linseed oil paint acted as "medium" $\left(15-150 \mathrm{~g} /\left(\mathrm{m}^{2} \mathrm{~d}\right)\right.$.

\section{METHOD AND EQUIPMENT}

To distinguish the moisture buffering abilities of plaster, the Nordtest method for determining the MBV of composite systems open to indoor climate was used [3]. The temperature was $23 \pm 0.5{ }^{\circ} \mathrm{C}$ throughout the experiment. Firstly, the specimens were kept in an environment with relative humidity (RH) at $50 \pm 5 \%$ until an equilibrium (the change in the specimen mass is under $1 \%$ during two weighings performed every 24 hours) was achieved. Then relative humidity was increased by $75 \%$ for 8 hours and decreased by $33 \%$ for 16 hours. The cycle was repeated until the average change in mass $\Delta \mathrm{m}(\mathrm{g})$ during three consecutive cycles was within $5 \%$.

The Nordtest protocol formula for $\mathrm{MBV}_{\text {practical }}\left[\mathrm{g} /\left(\mathrm{m}^{2} \cdot \% \mathrm{RH}\right)\right]$ calculations:

$$
M V B_{8 h}=\frac{m_{\max }-m_{\min }}{A \cdot\left(\varphi_{\text {high }}-\varphi_{\text {low }}\right)},
$$

where $\mathrm{m}_{\min / \max }$ is moisture mass ( $\min$ and max) in the final sample ( $\mathrm{g}$ or $\mathrm{kg}$ ); $\mathrm{A}$ is exposed area $\left(\mathrm{m}^{2}\right) ; \varphi_{\text {high/low }}$ is high/low RH (75-33) levels applied in the measurement.

According to the Nordtest method, specimens need to be weighed five times during one cycle [3]. We weighed specimens two times per cycle as the data from only two weighings were needed to calculate the MBV (Eq. (1)).

The equipment included the climate chamber RUMED 4101 affording RH $20 \ldots 95 \%$ with an accuracy of $\pm 2-3 \%$ and temperature of $0 \ldots 60{ }^{\circ} \mathrm{C}$ with an accuracy of $\pm 0.5^{\circ} \mathrm{C}$; Memmert Incubator Oven INB200 with temperature range from +30 ${ }^{\circ} \mathrm{C}$ (however, at least $5{ }^{\circ} \mathrm{C}$ above ambient) up to $+70{ }^{\circ} \mathrm{C}$ and digital balance Kern PLT 1200-3A with an accuracy of 0.001 g. Climate chamber method was used at an environment temperature of $23 \pm 0.5^{\circ} \mathrm{C}$.

To evaluate the effect of moisture buffering to the room borders, daily hygroscopic inertia of the room $\left[I_{\mathrm{h}, \mathrm{d}} \mathrm{g} /\left(\mathrm{m}^{30} \% \mathrm{RH}\right)\right]$ defined by Ramos and others [13], [14] could be calculated:

$I_{h, d}=\frac{\sum_{i}^{n} M B V_{i} \cdot S_{i}+\sum_{j}^{m} M B V_{o b j}}{a c h \cdot V \cdot t_{g}}$,

where $\mathrm{MBV}_{\mathrm{obj}}, \mathrm{MBV}_{\mathrm{i}}$ - moisture buffering value of objects and elements; $S_{i}$ - the surface of an element i $\mathrm{m}^{2}$; ach - air exchange rate $\mathrm{h}^{-1} ; \mathrm{V}$ - room volume $\mathrm{m}^{3} ; \mathrm{t}_{\mathrm{g}}$ - vapour production period, $\mathrm{h}$.

\section{SPECIMENS AND COLOURS}

The specimens were made according to the recipe that contains waste paper (news- paper paper), glue (methylcellulose produced by Henkel) and water. After drying 
the specimens were covered with paint.

Two different groups of specimens were made. The first group was used to study the effects of different paints on the MBV and the second group - to study the effects of different numbers of paint layers on the MBV.

The total number of specimens in the first group was $24(3 \times 8)$. Seven different colours were used to paint the specimens (casein primer, casein paint, tinted casein colour, linseed oil paint, egg oil tempera, clay paint and alkyd paint Akrit 7). The specimens were covered with two layers of paint (Fig. 1, Table 1).

Group 1 of specimens. Unpainted specimens.

Groups 2-4 of specimens. Casein paint is a natural interior colour with long traditions and is a suitable finish for natural plasters in a dry indoor environment. Casein colours enable water vapour to move through the plastered surfaces. All three casein colours (primer, white and tinted colour) were made of fat-free curd, borax (sodium tetraborate $\left(\mathrm{Na}_{2} \mathrm{~B}_{4} \mathrm{O}_{7}\right)$ ) and water. Casein primer is used to prime the surface. White casein paint is achieved by adding chalk (calcium carbonate $\left(\mathrm{CaCO}_{3}\right)$ ) to the primer and different tones by adding coloured soils to the primer, which has been previously whitened by chalk.

Casein primer (Group 2 of specimens): $10 \mathrm{~g}$ borax (sodium tetraborate $\left.\left(\mathrm{Na}_{2} \mathrm{~B}_{4} \mathrm{O}_{7}\right)\right)+$ $30 \mathrm{ml}$ water (temp $70^{\circ} \mathrm{C}$ ) $+250 \mathrm{~g}$ curd (fatfree), promote casein hydrolysis +11 water.

Casein paint (Group 3 of specimens): $10 \mathrm{~g}$ borax $+30 \mathrm{ml}$ water $\left(\right.$ temp $\left.70{ }^{\circ} \mathrm{C}\right)+$ $250 \mathrm{~g}$ curd (fat-free), promote casein hydrolysis +11 water $+400 \mathrm{~g}$ chalk (calcium carbonate $\left(\mathrm{CaCO}_{3}\right)$ ).

Tinted casein paint (Group 4 of specimens): $10 \mathrm{~g}$ borax (sodium tetraborate $\left.\left(\mathrm{Na}_{2} \mathrm{~B}_{4} \mathrm{O}_{7}\right)\right)+30 \mathrm{ml}$ water $\left(\right.$ temp $\left.70{ }^{\circ} \mathrm{C}\right)+$ $250 \mathrm{~g}$ curd (fat-free), promote casein hydrolysis +11 water $+400 \mathrm{~g}$ chalk (calcium car- bonate $\left.\left(\mathrm{CaCO}_{3}\right)\right)+$ yellow synthetic iron oxide (ferric oxide yellow) $\left(\mathrm{Fe}_{2} \mathrm{O}_{3}\right)$.

Group 5 of specimens. Linseed oil paint is absorbed deep into the surface; hence, it has very permanent traits as it fills the pores on the surface and does not form a membrane on it. Linseed oil paint is used to cover wooden parts. Linseed oil produced by Kemet RV Ltd, which has a cold-pressed oil made of linseed as a binder, was used.

Group 6 of specimens. Egg oil tempera is a glaze paint, which has raw egg and linseed oil as binders, water as a dissolvent and pigments are added for tinting. Out of all the natural paints, egg oil tempera is one of the most washable and wearproof colours, which is also suitable to use in humid rooms. Suitable surfaces include wood and plastered surfaces. Egg oil tempera was made using equal parts (volume) of water, linseed oil (by Kemet RV Ltd) and raw eggs.

Group 7 of specimens. The surface of clay colour is rough; it has a lot of pores and does not tolerate mechanical stress. Clay paint can be used on all mineral and waterabsorbing surfaces. Clay colour was made of clay finishing plaster by OÜ Saviukumaja. It consists of clay, sand (grain size 0-2 $\mathrm{mm}$ ) and fibres of Typha stem. X-ray diffraction analysis was used to determine the mineralogical composition (\% of mass) of the clay plaster mixture $(<0.2 \mathrm{~mm})$ : quartz 45.6, k-feldspar 6.6, plagioclase 7.9, chlorite 1.5 , illite/illite-smectite 20.9 , kaolinite 4.1 , calcite 8.5 , dolomite 4.0 , hematite 0.5 and amphibole $0.5 \mathrm{wt} \%$ [15]. Clay paint was made by mixing $500 \mathrm{~g}$ of clay finishing plaster mixture (fraction 0.25) with $250 \mathrm{~g}$ of water.

Group 8 of specimens. Alkyd paint Akrit 7 is a water-based acrylate paint (produced by Eskaro Group AB Sweden) intended to be used indoors as a finishing product in dry rooms and rooms with elevated humidity. 


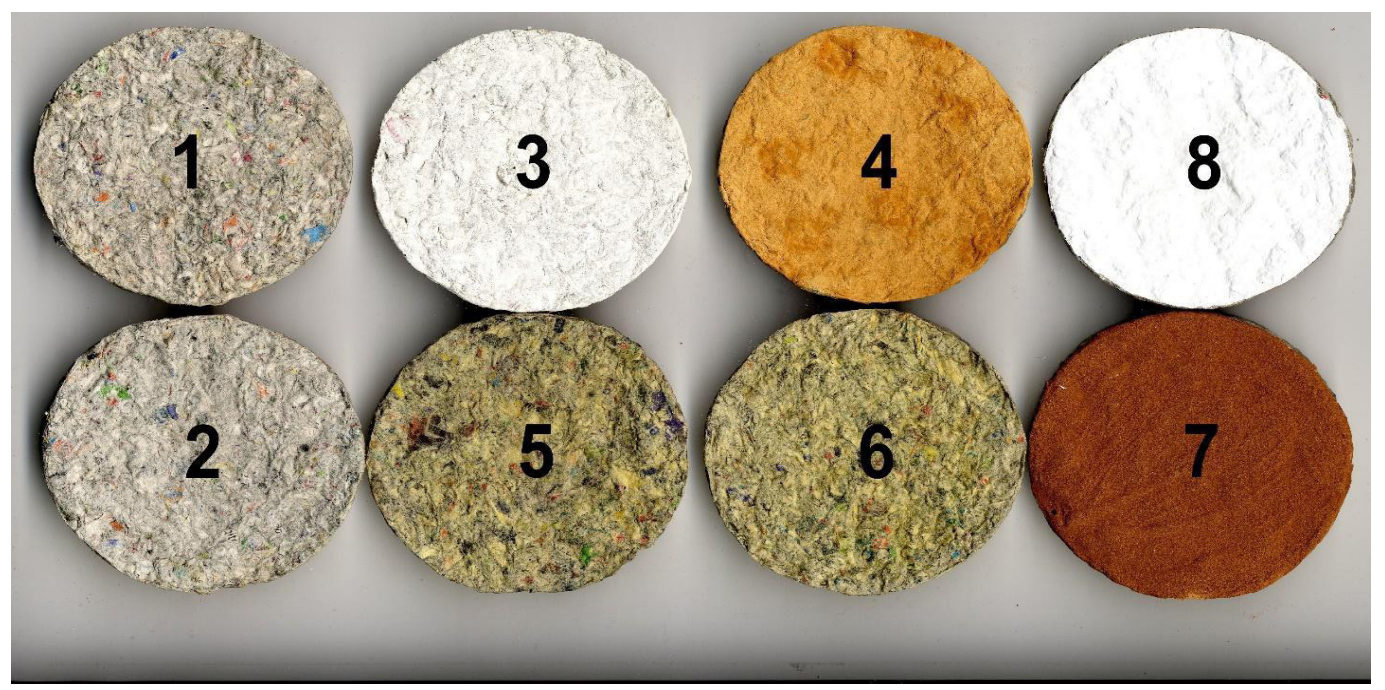

Fig. 1. Examples of specimen groups:

1 - unpainted, 2 - casein primer, 3 - casein paint, 4 - tinted casein colour, 5 - linseed oil paint, 6 - egg oil tempera, 7 - clay colour, 8 - alkyd paint Akrit 7.

Table 1. Colours

\begin{tabular}{|l|c|c|c|c|c|}
\hline $\begin{array}{l}\text { Plaster group } \\
\text { number }\end{array}$ & Colour & $\begin{array}{c}\text { No. of painted } \\
\text { layers }\end{array}$ & Paper (g) & $\begin{array}{c}\text { Glue (g) } \\
\text { Glue/water }\end{array}$ & $\begin{array}{c}\text { No. of } \\
\text { samples }\end{array}$ \\
\hline 1 control & Unpainted & 0 & 500 & $20 / 1000$ & 3 \\
\hline 2 & Casein primer & 2 & 500 & $20 / 1000$ & 3 \\
\hline 3 & Casein paint & 2 & 500 & $20 / 1000$ & 3 \\
\hline 4 & Tinted casein paint & 2 & 500 & $20 / 1000$ & 3 \\
\hline 5 & Linseed oil paint & 2 & 500 & $20 / 1000$ & 3 \\
\hline 6 & Egg oil tempera & 2 & 500 & $20 / 1000$ & 3 \\
\hline 7 & Clay paint & 2 & 500 & $20 / 1000$ & 3 \\
\hline 8 & Alkyd paint Akrit 7 & 2 & 500 & $20 / 1000$ & 3 \\
\hline
\end{tabular}

The second experiment focused on the effects of the natural colour thickness (number of layers) on the MBV. Two colours were used to paint the specimens: casein colour and clay colour. The total number of specimens was 60 ( $3 \times 20)$. The specimens were covered with casein colour once, twice or, 5, 10, 15 and 20 times (Fig. 2, Table 2) and with clay colour once, twice, or 3, 4, 5, and 6 times (Fig. 3, Table 2). After each layer was painted, the specimens were left to dry. The experiment included the socalled control group, which consisted of unpainted specimens. 


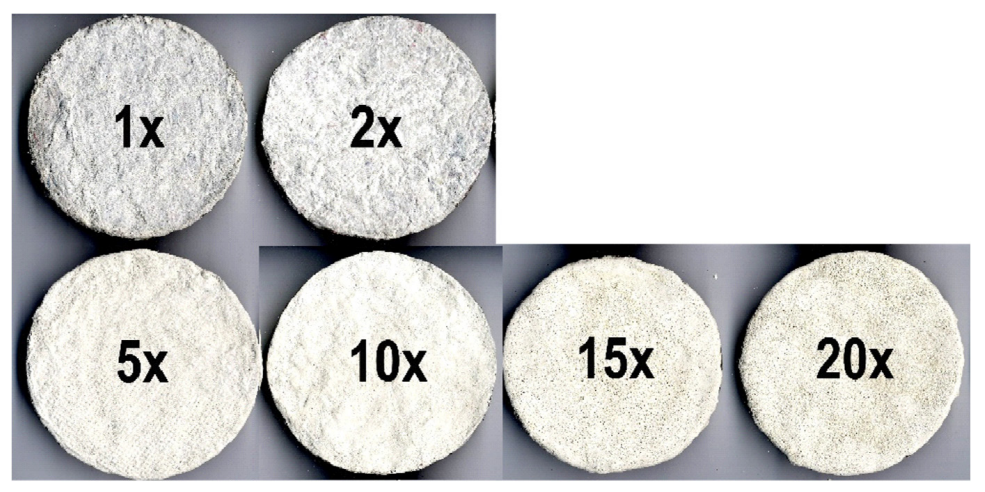

Fig. 2. Examples of specimen groups 2-7. Specimens covered with casein colour and the number of paint layers.

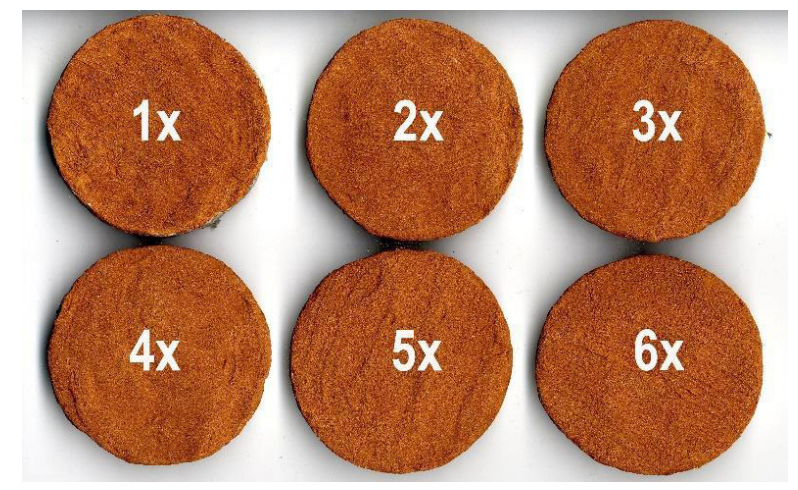

Fig. 3. Examples of specimen groups 8-13. Specimens covered with clay colour and the number of paint layers.

Table 2. Paint Layers

\begin{tabular}{|l|c|c|c|c|c|}
\hline $\begin{array}{l}\text { Plaster } \\
\text { group } \\
\text { number }\end{array}$ & Colour & $\begin{array}{c}\text { No. of paint } \\
\text { layers }\end{array}$ & Paper (g) & $\begin{array}{c}\text { Glue (g) } \\
\text { Glue/water }\end{array}$ & $\begin{array}{c}\text { No. of } \\
\text { samples }\end{array}$ \\
\hline 1 control & Unpainted & 0 & 500 & $20 / 1000$ & 3 \\
\hline 2 & Casein paint & 1 & 500 & $20 / 1000$ & 3 \\
\hline 3 & Casein paint & 2 & 500 & $20 / 1000$ & 3 \\
\hline 4 & Casein paint & 5 & 500 & $20 / 1000$ & 3 \\
\hline 5 & Casein paint & 10 & 500 & $20 / 1000$ & 3 \\
\hline 6 & Casein paint & 15 & 500 & $20 / 1000$ & 3 \\
\hline 7 & Casein paint & 20 & 500 & $20 / 1000$ & 3 \\
\hline 8 & Clay paint & 1 & 500 & $20 / 1000$ & 3 \\
\hline 9 & Clay paint & 2 & 500 & $20 / 1000$ & 3 \\
\hline 10 & Clay paint & 3 & 500 & $20 / 1000$ & 3 \\
\hline 11 & Clay paint & 4 & 500 & $20 / 1000$ & 3 \\
\hline 12 & Clay paint & 5 & 500 & $20 / 1000$ & 3 \\
\hline 13 & Clay paint & 6 & 500 & $20 / 1000$ & 3 \\
\hline
\end{tabular}




\section{RESULTS}

Results achieved with the Nordtest method describe the moisture absorption and desorption of painted paper plaster surfaces and it is expressed with an index MBV. The change in relative moisture in actual living spaces is described by $\mathrm{MBV}_{\text {practical }}[16]$. As a result of changing relative humidity in cycles, the weight of the specimens also changed in cycles (see Fig. 4). According to the MBV $\left[\mathrm{g} /\left(\mathrm{m}^{2} . \% \mathrm{RH}\right) @ 8 / 16 \mathrm{~h}\right]$, materials can be classified as follows: negligible $(0-0.2)$, limited $(0.2-0.5)$, moderate $(0.5-$ $1.0)$, good (1.0-2.0), and excellent (2.0-) [10].

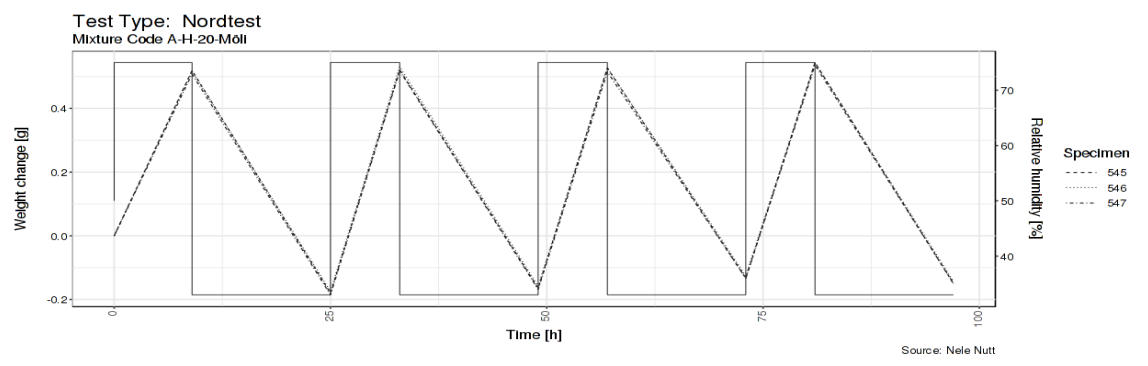

Fig. 4. Changes in specimen weight (only weight change) in the final cycles (plaster group 7).

The change in moisture cycles (RH $33 \%$ and RH $75 \%$ ) in the climate chamber is portrayed by a solid line (Fig. 6, Table 4).

The results of the experiment with different colours showed that the MBV was highest (2.88 g/(m2.\%RH)@8/16h) for unpainted paper plaster (plaster group 1). All the MBVs of paint covered specimens were lower (Fig. 5, Table 3). The MBVs of specimens that were covered with casein colour (plaster groups 2, 3, 4) and clay colour (plaster group 7) were a little lower than the unpainted paper plaster specimens.
Their MBV was higher than $2.0[\mathrm{~g} /$ (m².\%RH)@8/16h] (excellent). Specimens painted with egg oil tempera also had MBV higher than $2.0 \quad\left[\mathrm{~g} /\left(\mathrm{m}^{2} . \% \mathrm{RH}\right) @ 8 / 16 \mathrm{~h}\right]$ (excellent). However, the MBV of specimens covered with linseed oil colour was smaller than $2.0 \quad\left[\mathrm{~g} /\left(\mathrm{m}^{2.0} \% \mathrm{RH}\right) @ 8 / 16 \mathrm{~h}\right]$ (good) and the specimens painted with alkyd paint Akrit 7 (plaster group 8) had MBV smaller than $1.0 \quad\left[\mathrm{~g} /\left(\mathrm{m}^{2} . \% \mathrm{RH}\right) @ 8 / 16 \mathrm{~h}\right]$ (moderate) (Fig. 5, Table 3).

Table 3. MBV of Speciments

\begin{tabular}{|l|c|c|c|}
\hline Plaster group number & $\begin{array}{c}\text { MBV } \\
{\left[\mathbf{g} /\left(\mathbf{m}^{\mathbf{2}} \mathbf{\%} \mathbf{R H}\right) @ \mathbf{8} / \mathbf{1 6 h}\right]}\end{array}$ & $\begin{array}{c}\text { MBV } \\
\text { classification }\end{array}$ & $\mathbf{I}_{\mathbf{h}, \mathbf{d}}, \mathbf{g} /\left(\mathbf{m}^{\mathbf{3}} \mathbf{\%} \mathbf{R H}\right)$ \\
\hline 1 & 2.88 & excellent* $^{*}$ & 0.51 \\
\hline 4 & 2.70 & excellent* $^{*}$ & 0.48 \\
\hline 2 & 2.63 & excellent* $^{*}$ & 0.47 \\
\hline 7 & 2.61 & excellent* $^{*}$ & 0.46 \\
\hline 3 & 2.42 & excellent* & 0.43 \\
\hline 5 & 2.34 & excellent* & 0.35 \\
\hline 8 & 1.96 & good* & 0.10 \\
\hline
\end{tabular}

*negligible (0-0.2), limited (0.2-0.5), moderate (0.5-1.0), good (1.0-2.0), excellent (2.0-). 


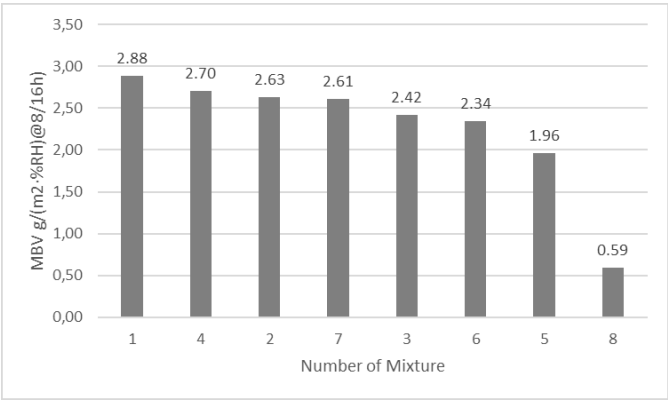

Fig. 5. MBV of specimens: 1 - unpainted, 2 - casein primer, 3 - casein paint, 4 - tinted casein colour, 5 - linseed oil colour, 6 - egg oil tempera, 7 - clay colour, 8 - alkyd paint Akrit 7.

The results of the experiment studying the effects of paint layers on the MBV showed that the more the layers, the lower the MBV (Fig. 6, Tabel 4).

Example: If we take a living room (walls) with measurements $5 \cdot 4 \cdot 2.6 \mathrm{~m}$ (windows and doors approx. $4 \mathrm{~m}^{2}$ ), where ventilation rate according to energy efficiency requirements is $0.42 \mathrm{l} /\left(\mathrm{sm}^{2}\right)$, (air change $0.58 \mathrm{~h}^{-1}$ and time 8 hours), it is possible to calculate (Eq. (2)) the results of hygrothermal inertia index of the room (Tables 3 and 4).

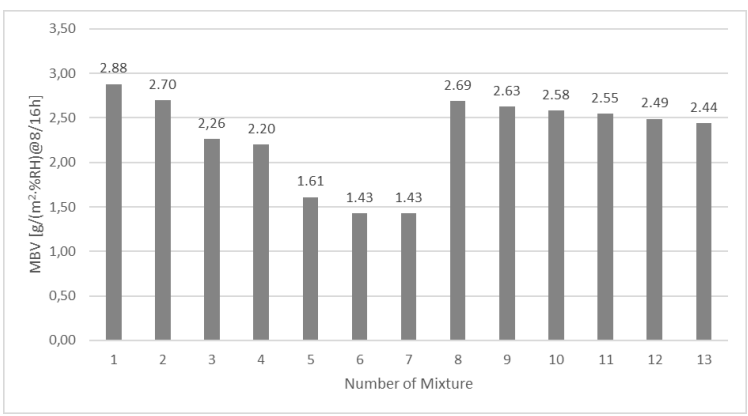

Fig. 6. MBV of mixtures: 1 - unpainted, 2-7 casein paint, $8-13$ clay paint.

Table 4. MBV of Mixtures

\begin{tabular}{|l|c|c|c|c|}
\hline $\begin{array}{l}\text { Plaster group } \\
\text { number }\end{array}$ & $\begin{array}{c}\text { No. of paint } \\
\text { layers }\end{array}$ & $\begin{array}{c}\text { MBV } \\
{\left[\mathbf{g} /\left(\mathbf{m}^{\mathbf{2}} \mathbf{0} \mathbf{R H}\right) @ \mathbf{8} / \mathbf{1 6 h}\right]}\end{array}$ & $\begin{array}{c}\mathbf{M B V} \\
\text { classification }\end{array}$ & $\mathbf{I}_{\mathbf{h}, \mathbf{d}} \mathbf{g} /\left(\mathbf{m}^{\mathbf{3}} \mathbf{\%} \mathbf{R H}\right)$ \\
\hline 1 control & 0 & 2.88 & excellent* & 0.51 \\
\hline 2 & 1 & 2.70 & excellent* & 0.48 \\
\hline 3 & 2 & 2.26 & excellent* & 0.40 \\
\hline 4 & 5 & 2.20 & excellent* & 0.39 \\
\hline 5 & 10 & 1.61 & good* $^{*}$ & 0.28 \\
\hline 6 & 15 & 1.43 & good* $^{*}$ & 0.25 \\
\hline 7 & 20 & 1.43 & good* & 0.25 \\
\hline 8 & 1 & 2.69 & excellent* & 0.48 \\
\hline 9 & 2 & 2.63 & excellent* & 0.47 \\
\hline 10 & 3 & 2.58 & excellent* & 0.46 \\
\hline 11 & 4 & 2.55 & excellent* & 0.45 \\
\hline 12 & 5 & 2.49 & excellent* & 0.44 \\
\hline 13 & 6 & 2.44 & excellent* & 0.43 \\
\hline
\end{tabular}

*negligible (0-0.2), limited (0.2-0.5), moderate (0.5-1.0) good (1.0-2.0), excellent (2.0-). 


\section{CONCLUSION AND DISCUSSION}

Our experiment showed that:

- The MBV of paper plaster was affected when covered with paint. Unpainted paper plaster had the MBV of $2.88 \mathrm{~g} /$ $\left(\mathrm{m}^{2} . \% \mathrm{RH}\right) @ 8 / 16 \mathrm{~h}$. All the MBVs of paint covered paper plasters were under $2.70 \mathrm{~g} /\left(\mathrm{m}^{2} . \% \mathrm{RH}\right) @ 8 / 16 \mathrm{~h}$.

- Colours had a different impact on the MBV of paper plaster. Out of all the natural colours, casein and clay colours inhibited the MBV the least. Their MBVs stayed within 2.70-2.42 g/ (m².\%RH)@8/16h.

- MBVs of all casein colours (casein primer, casein paint, tinted casein colour) were different from each other but stayed between 2.70 and $2.42 \mathrm{~g} /$ (m%RH)@8/16h. Tinted casein colour had the highest MBV of 2.70 $\mathrm{g} /\left(\mathrm{m}^{2} . \% \mathrm{RH}\right) @ 8 / 16 \mathrm{~h}$. It was followed by casein primer with $\mathrm{MBV}$ of 2.63 $\mathrm{g} /\left(\mathrm{m}^{2 . \%} \mathrm{RH}\right) @ 8 / 16 \mathrm{~h}$ and casein paint with MBV of $2.42 \mathrm{~g} /\left(\mathrm{m}^{2 .} \% \mathrm{RH}\right) @ 8 / 16 \mathrm{~h}$.

- MBV of paper plaster decreased significantly as the number of casein colour layers increased. MBV was $2.70 \mathrm{~g} /$

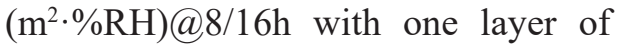
colour, 2.20 after 10 layers and $1.43 \mathrm{~g} /$ (m².\%RH)@8/16h after 20 layers had been applied.

- From the colours containing oil, linseed oil paint was the one that inhibited the MBV of paper plaster and it was $2.61 \mathrm{~g} /$ (m².\%RH)@8/16h.

- MBV of egg oil tempera covered paper plaster was the lowest at $0.59 \mathrm{~g} /$ (m².\%RH)@8/16h.

- The effect of clay colour on the MBV was notable. When the MBV of unpainted paper plaster was $2.88 \mathrm{~g} /$ $\left(\mathrm{m}^{2} . \% \mathrm{RH}\right) @ 8 / 16 \mathrm{~h}$, then the MBV of clay colour covered specimens was $2.63 \mathrm{~g} /\left(\mathrm{m}^{2} . \% \mathrm{RH}\right) @ 8 / 16 \mathrm{~h}$.
- The number of layers (1-6) was influential for clay colour covered specimen. The MBV decreased with each added layer of clay colour. When the MBV of paper plaster with one layer of colour was $2.69 \mathrm{~g} /\left(\mathrm{m}^{2 . \%} \mathrm{RH}\right) @ 8 / 16 \mathrm{~h}$, then after six layers the MBV was $2.44 \mathrm{~g} /$ (mºRH)@8/16h.

Literature states [17] that casein colour does not inhibit the movement of water vapour through the plaster surface. However, our experiment showed that the MBV depended, firstly, on the composition of casein colour and, secondly, on the number of paint layers.

If a pigment is added to tone white casein colour, which is made with chalk, then the MBV is affected. At the same time, it should be taken into consideration that different pigments have a different chemical composition; thus, they can have both positive and negative effects on the MBV. It is necessary to study how different pigments affect the MBV of a tinted casein colour. This, in particular, is important as the chemical reactions between paper plaster (cellulose) and paint may affect the MBV. Also when making paper plaster, the cellulose hydrogen $(\mathrm{H})$ is replaced by methyl $\left(\mathrm{CH}_{3}\right)$ radicals; hence, the possibility to form hydrogen bonds decreases.

Priming wall surfaces is a common method used to decrease painting costs. Primers are cheap because they have no pigment. Casein primer is intended to be used on walls with casein paint. Our experiment showed that the MBV was higher for the wall surface covered with casein primer than with only casein paint. Therefore, we recommend using casein primer as the first layer when painting paper plaster with casein colours. In the future, the effects of 
different combinations of casein primer and casein paints on the MBV should be studied.

It cannot unequivocally be said that casein colour enables the water vapour to move through surfaces as the previously mentioned literature states because the MBV of paper plastered surfaces decreases when the walls are repeatedly covered with casein colour (whitened during renovation). As new casein paint is directly added on top of the old casein colour layer, it should be taken into consideration that continuously adding paint layers will decrease the MBV of the wall surface.

Applying paper plaster does not require specific skills on the contrary to the application of clay plaster, and, therefore, it is executable by anyone. If the intent is to achieve a wall that replicates clay plaster, a good solution is to paint paper plastered walls with clay colour. However, it should be considered that each added layer of clay colour decreases the MBV of that wall. The same effect occurs when painting with casein paint.

Linseed oil and egg oil tempera both contain linseed oil. Linseed oil is absorbed deep into the surface and fills the pores; thus, the paper plaster covered with linseed oil has a lower MBV than the one covered with egg oil tempera. However, egg oil tempera is wearproof and washable and also suitable for humid spaces.

Calculation of daily hygroscopic iner- tia gives us information about the influence of MBV on the room together with ventilation and service area. Sample calculation was made for a case when ventilation is according to energy performance requirements $\left[0.421\left(/ \mathrm{sm}^{2}\right)\right]$ and the whole wall area is acting. By using this calculation, everybody can find a suitable solution for different materials, ventilation rates, service areas and time to reduce peaks of $\mathrm{RH}$ variation.

Our experiments showed that the MBV of paper plastered and painted wall surfaces depended on the chosen colour and the number of applied layers of that colour. Further research should entail the study of other hygroscopic abilities of painted paper plaster. In addition to the MBV and the densities of materials studied in the research, the behaviour of other parameters should also be examined. Further research should also start to observe other moisture properties. The method described in the standard "EVS-EN ISO 12571:2013 Hygrothermal performance of building materials and products - Determination of hygroscopic sorption properties" [18] is used to study the sorption of water vapour when determining the hygroscopicity of porous materials. To study the conductivity of water vapour, the method from "EVS-EN ISO 12572:2016 Hygrothermal performance of building materials and products - Determination of water vapour transmission properties - Cup method" [19] was used.

\section{ACKNOWLEDGEMENTS}

This study has been supported by Tartu College of Tallinn University of Technology.
The authors would like to thank Kadri Mets for improving English of the manuscript.

\section{REFERENCES}

1. Minke, G. (2006). Building with earth: Design and technology of a sustainable architecture. Basel: Birkhäuser.
2. Mazhoud, B., Collet, F., Pretot, S., \& Chamoin, J. (2016). Hygric and Thermal Properties of Hemp-Lime Plasters. Build 
Environment, 96, 206-216.

3. Rode, C. (2005). Moisture buffering of building materials. BYG DTU126 Report. Department of Civil Engineering, Technical University of Denmark, Kongens Lyngby.

4. Svennberg, K. (2006). Moisture Buffering in the Indoor Environment. $\mathrm{PhD}$ Thesis. Lund: Lund University.

5. Zhang, M., Qin, M., \& Chen, Z. (2017). Moisture Buffer Effect and Its Impact on Indoor Environment. Procedia Engineering, 205, 1123-1129. DOI: 10.1016/j.proeng.2017.10.417

6. Teearu, M.-L. (2018). Paberkrohvi niiskustehniliste omaduste määramine: sorptsioon, veeauru läbilaskvus ning niiskuspuhverdusvõime [Determinantion of Hygrothermal Performance of Paper Clay: Sorption, Water Vapour Permeability and Moisture Buffering]. Master's Thesis. Tallinn: Tallinn University of Technology. (In Estonian)

7. Nutt, N., Kubjas, A., \& Nei, L. (2020). Adding Waste Paper to Clay Plaster to Raise Its Ability to Buffer Moisture. Proceedings of the Estonian Academy of Sciences, 69 (3), 179-185. DOI: 10.3176/proc.2020.3.01

8. Nutt, N., \& Kubjas, A. (2020). Moisture Buffer Value of Composite Material Made of Clay-Sand Plaster and Wastepaper. Journal of Sustainable Architecture and Civil Engineering, 2 (26).

9. Soolepp, M., Ruus, A., Nutt, N., Raamets, J., \& Kubjas, A. (2020). Hygrothermal performance of paper plaster: influence of different types of paper and production methods on moisture buffering. E3S Web Conf., 172. 2020 12th Nordic Symposium on Building Physics (NSB 2020) https://doi. org $/ 10.1051 / \mathrm{e} 3$ sconf $/ 202017214010$

10. Vares, O., Ruus, A., Raamets, J., \& Tungel, E. (2017). Determination of Hygrothermal Performance of Clay Sand Plaster: Influence of Covering on Sorption and Water Vapour Permeability. Energy Procedia, 132, 267272. DOI: 10.1016/j.egypro.2017.09.719

11. Soosaar, H. (2017). Pinnakatte mõju savikrohvi hügroskoopsusele ja veeauru läbilaskvusele [Influence of Finishing on Clay Plaster Hygroscopicity and Water
Vapour Permeability]. Master's Thesis. Tallinn: Tallinn University of Technology. (In Estonian)

12. Ruus, A., Peetsalu, P., Tohvri, E., Lepasaar, T., Kirtsi, K., Muoni, H. ... \& Kabanen, T. (2011). Water Vapour Transmission Properties of Natural Paints. Agronomy Research, 9 (Biosystem Engineering Special Issue 1), 197-201.

13. Ramos, N.M.M., \& Freitas, V.P. (2008). Laboratory testing for daily hygroscopic inertia assessment. In 8th Symposium on Building Physics in the Nordic Countries, 16-18 June 2008 (pp. 809916). Copenhagen, Denmark: Technical University of Denmark.

14. Ramos, N. M. M., Delgado, J. M. P. Q. \& Freitas, V. P. (2010). Influence of Finishing Coatings on Hygroscopic Moisture Buffering in Building Elements. Construction and Building Materials, 24, 2590-2597.

15. Altmäe, E., Ruus, A., Raamets, J., \& Tungel, E. (2019). Determination of ClaySand Plaster Hygrothermal Performance: Influence of Different Types of Clays on Sorption and Water Vapour Permeability. In the 9th International Cold Climate Conference: Sustainable New and Renovated Buildings in Cold Climates, 12-15 March 2018 (pp. 945-955). Kiruna, Sweden: Lund University. DOI: 10.1007/978-3-030-00662-4_80

16. Janssen, H., \& Roels, S. (2009). Qualitative and Quantitative Assessment of Interior Moisture Buffering by Enclosures. Energy and Buildings, 41 (4), 382-394. DOI: 10.1016/j.enbuild.2008.11.007

17. Pere, R., \& Elvisto, T. (2009). Looduslikud värvid ehituses [Natural paints in construction] Tallinn: Ajakirjade kirjastus. (In Estonian)

18. EVS-EN ISO 12571:2013 Hygrothermal performance of building materials and products - Determination of hygroscopic sorption properties.

19. EVS-EN ISO 12572:2016 Hygrothermal performance of building materials and products - Determination of water vapour transmission properties - Cup method. 